\title{
EVOLVING MONETARY ECONOMICS IN ISLAMIC PERSPECTIVE
}

\author{
Muhammad Ayub ${ }^{1}$ and M. Fahim Khan ${ }^{2}$ \\ ${ }^{1}$ Riphah International University, Islamabad, muhammad.ayub@riphah.edu.pk \\ ${ }^{2}$ Markfield Institute of Higher Education, UK, mfahimkhan@hotmail.com
}

\begin{abstract}
The challenges facing the Islamic banking and finance industry include, inter alia, resolving the issue of 'form over substance', adopting value-based social and ethical finance, and reinforcing public confidence that its business and services conform to the principles of Shari'ah in both letter and spirit. These challenges can be faced only if Islamic finance is based on the money and monetary perspective of Islamic economics. An important aspect for discussion in this context is the issue of money creation. This paper is based on an analysis of the literature on conventional and Islamic economics and Islamic finance. It comprises observational and narrative research mainly because monetary policy from an Islamic perspective has not been implemented in any jurisdiction in the modern world. Its objective is thus to suggest how monetary policy might evolve from the perspective of Islamic law of contracts. It discusses an economic model in which a new theory of monetary economics could become a basis for evolving Islamic finance in its value-based perspective. It also discusses monetary economics and monetary policy from an Islamic perspective in the context of contemporary Muslim economies. The Islamic financial system must be based on the Islamic system of money, monetary economics and exchange principles. Hence, economists and policymakers may first focus on evolving monetary economics and policy from an Islamic perspective, to serve as a basis for structural reforms.
\end{abstract}

Keywords: Islamic economics, Money and monetary economics, Islamic banking and finance. JEL classification: E51; E52; G2; Z12.

Article history:

Received : October 10, 2020

Revised : March 10, 2021

Accepted : : March 15, 2021

Available online : May 20, 2021

https://doi.org/10.21098/jimf.v7i2.1372 


\section{INTRODUCTION}

\subsection{Background}

Monetary policy and hence, monetary economics, was not a subject in the economies of the Muslim world until the $18^{\text {th }}$ century, when they lost their economic power and independence. This was the period when Adam Smith developed the so-called Science of Economics. The Classical theory of economics that emerged in the $18^{\text {th }}$ century was not very enthusiastic with regard to monetary economics and macroeconomics. It was instead concerned with real aspects of the economy. Macroeconomics and for its part monetary economics emerged following the rejection of Classical theory that resulted from Adam Smith's book 'The Wealth of Nations'.

Monetary economics and macroeconomics evolved only during and after the so-called Great Depression, when John Maynard Keynes's 'General Theory of Employment, Interest and Money' appeared in 1936 describing macroeconomic concepts and explaining fluctuations in the market in the context of the real sector. Monetary policy required the role of central banks in the creation of credit and also commercial banks for interest-based borrowing and lending with respect to managing growth and the stability of the economy. During this period, most of the Muslim world was under colonial rule with no development of monetary policy in their economies and thus no form of economics that could be referred to as Islamic economics or Islamic monetary policy.

Following independence from colonial rule, Muslim countries inherited interest-based commercial banking and hence a colonial macroeconomic framework, as well as monetary policy. This led economists in Muslim countries to study and follow Keynesian economics and thus to focus primarily on the growth and stability of their economies. Keynesian economics had generally become a standard model in the developed world on account of interest-based commercial and central banking. It became the basis of modern global finance. The abandonment of the Gold Standard, followed by the inter-war period (1914-44), the Bretton-woods system and, finally, the Nixon shock (1971) led increasingly to the creation of money and credit and to those who held financial assets grabbing wealth at both the national and global levels. In particular, the creation of US dollars (paper gold) created imbalances in global finance and led to the devastation of human societies in wars.

A specific contribution or novelty of this paper is that it suggests evolving monetary economics while linking money, credit and finance with the real economy. It recommends a policy approach in an alternative paradigm based on Islamic principles of wealth creation and its exchange.

\subsection{Objective}

This paper suggests ways in which monetary policy can be evolved from the perspective of Islamic law of contracts. It does not focus on what the nature of money should be, i.e. bullion/commodity money, paper/fiat money or crypto/ digital money, but discusses mainly the bases and methods of money and credit 
creation that form the overall supply of money that is currently understood as the sum of M0, M1 ... M41.

Money, credit and monetary factors play an important role in creating inflation and ultimately in channelling the national wealth to those who have excess money and invest it in debt-based risk-free financial assets. The paper discusses an economic model in which a theory of monetary economics could tackle the above problem and become a basis for developing Islamic finance to realise socioeconomic objectives. It also encourages economists and economic policymakers to explore the evolution and functioning of beyond-market institutions that constitute a strategic part of Islamic economics. As suggested by Gómez (2020), such an approach emphasises institutional competence to achieve greater social integration with sustainable growth.

The paper aims to contribute to evolving monetary economics and monetary policy not only from an Islamic perspective but also in the context of contemporary Muslim economies.

The remainder of the paper is structured as follows. Section Two discusses the evolution of Islamic economics and finance; Section Three contains a review of the literature, while Section Four elaborates economics from an Islamic perspective. Section Five discusses monetary economics from the Islamic perspective, Section Six discusses monetary policy in the economies of present-day Islamic countries, and finally, Section Seven provides a conclusion and recommendations.

\section{EVOLUTION OF ISLAMIC ECONOMICS AND FINANCE}

It was initially a weak realisation in the late 1960s and then a more forceful one in the 1970s when the Muslim world realised they had their own economic model based on Islamic Shariah as an alternative to following the interest-based structure of developed countries. Islamic law pertaining to economic activity, business and finance addresses sales, leasing, guarantees, partnership and other contracts as provided in Islamic law of contracts (McMillen, 2007).

Over the last four decades, Islamic finance has registered visible growth and global Islamic finance assets are expected to reach \$3.69 trillion by 2024 (RefinitivICD Report, 2020). The Refinitiv-ICD Report (2020) also highlighted the recent trend within Islamic finance for driving ahead with social finance, in line with the globally increasing focus on realising the SDGs. However, Islamic finance has thus far been unable to effect any change in respect of realising the objectives of Islamic economics and finance. The main reason for this is that all major Islamic banking products and finance products are based on the same paradigm of debt creation and trading. Islamic banking is rather considered to be a replica of conventional banking mainly since money and monetary policy play the same role as seen in the conventional capitalist system. Interest-bearing money is created without

\footnotetext{
1 M0 includes currency (notes and coins) plus bank reserves; M1 comprises currency (coins and notes) in circulation plus other money equivalents, which are readily convertible into cash (demand deposits); $M 2$ includes M1 plus short-term time deposits in banks and 24-hour money market funds; M3 includes M2 plus long-term time deposits and money market funds with more than 24 hours' maturity; and M4 includes M3 plus other deposits (Cf: Hanif, 2020).
} 
taking notice of its impact on income distribution, which is the fundamental cause of exploitation of the poor by the rich and the world's recurring economic and financial crises (Ayub, 2015).

The current application of the Islamic banking system and hence an Islamic economy with its own macroeconomic framework and monetary policy has faced many questions. The political ramifications combined with Western economic power and its influence on oil-producing economies has prevented rich Muslim countries from eliminating the entire interest-based financial and monetary systems that govern their economies. Therefore, a gradual approach has been taken to transforming their interest-based systems to an Islamic system through the partial introduction of Islamic banking in their economies. This quickly led to the introduction of Islamic banking by other Muslim countries in the Near East and Far East. But despite the efforts made during the last half-century, no Muslim country has succeeded in completely transforming its financial and monetary system into an Islamic one. However, the question arises as to how both the monetary sector and monetary policy would be managed in such an economy if 'interest' were to be eliminated.

Some Islamic economists believe that the rate of return on capital in the market can replace a country's interest-based financial structure, which in theory is a sensible proposition when certainty is assumed in economic (particularly investment) behaviour. Further, in the process of developing Islamic finance theory, money/finance capital has not been clearly differentiated from fixed capital. While fixed capital like land, buildings, plants, vehicles, machinery, etc. are eligible for any pre-agreed fixed return, money or financial capital cannot be assigned a fixed return, in line with the prohibition of riba. As a result, no contemporary Muslim economies have so far been able to implement monetary policy without 'interest' despite the visible development of Islamic banking and finance as indicated above.

\section{LITERATURE REVIEW}

Economists, researchers and Islamic finance professionals have written on the areas of money and monetary management in modern economies, including i) the present system of money and finance, its objective and impacts at the macro and micro levels; ii) the nature, feature and functions of money; iii) money as taken in banking and finance; iv) objectives of monetary policy and functions of the monetary authorities; v) money and reserve currencies for payments in international markets; and vi) monetary management tools, benchmarks and the need for monetary management.

\subsection{Present System of Money, its Objectives and Impacts}

Modern money and currency systems are based on the power of central banks to create money out of thin air; credit creation in the process of financial intermediation and the fractional reserve system (Hanif, 2020). In this system, money is viewed not only as a medium of exchange but also as a commodity for trade and an asset that can itself earn money. This is not possible in Islamic finance since the risk-reward concept of Islamic law is fundamentally different from the 
conventional concept of return on financial assets. In Islamic law, the use of money as a commodity is not acceptable and as such, money is not an asset that can itself earn money (McMillen, 2007). Every financial transaction must involve a tangible asset (leaving aside certain exceptions, such as intellectual property), McMillen (2007) adds.

Practically, to date, Islamic finance has ignored Shariah prohibitions on the payment or receipt of interest and other aspects relating to rib $\bar{a}$ and gharar. However, as indicated by Hanif (2020), some economists and finance experts have advocated a return of the currency system to the gold standard for the sake of stability and to inhibit the flow of wealth to the finance sector vis-à-vis the real sector.

The prevailing monetary system has many implications for the Islamic financial system (Hanif, 2020), but Islamic finance institutions have so far avoided them all by accepting the conventional paradigm. Hussain, Shahmoradi, and Turk (IMF WP/15/120, 2015) reported some authors as indicating that 'Islamic banks are not different from conventional banks' or there are 'few significant differences in business orientation, asset quality, efficiency, or stability'.

In terms of objectives, the existing money and credit system has failed to achieve the desired objectives of an equitable distribution of resources, stability in the financial system, the protection of wealth, etc. Debasement or overproduction of money causes inflation and other injustices (Hanif, 2020; Riazuddin, 2011). Abdullah (2016), Chapra (2008), Hanif (2020), and others have called for a 'reappraisal of [the] existing monetary management system' and the development of a reformed currency system at both the national and global levels for the stable and equitable growth of economies.

\subsection{The Nature and Feature of Money and Its Functions}

The most important feature of money is to serve as a measure and store of value. When an individual owns money, he owns about everything, unlike someone who owns cloth, for example, as he owns cloth and nothing else. In Islamic history, Muslim governments have officially used at least four types of currency, including gold, silver, copper and paper money (Hanif, 2020). As indicated by Hasan (2011), gold and silver coins were made in Lydian - modern Turkey - as early as around $560 \mathrm{BC}$ and could be regarded as the earliest forms of metallic coins. The states even debased the coins, based on the emblem, to lower the precious metal content. To that extent, coins became no better than notes printed on metal. Central banks came into existence mainly as a response to the inability of banks themselves to cope with panic, particularly in the inter-war period.

Hasan (2008a) builds convincing arguments against the use of gold currency for Muslim countries under prevailing circumstances. Shariah is neutral in terms of the type of currency used. Meera and Larbani (2009) reject the fiat money-based monetary system and declare the creation of money - currency and bank money - unlawful. They argue that the creation of purchasing power out of thin air by the central bank and commercial banks leads to injustice and instability. 
Hasan (2011) contended that the gold standard would work smoothly only if there were no structural rigidities in the economy - prices and wages, and public authorities were willing to surrender their discretion and independence to the automation requirements of the gold standard mechanism.

Hanif (2020) contends that a just and transparent currency system is expected to contribute to stability and the equitable distribution of wealth. He recommended the spending of seigniorage for the welfare of the community, the development of both asset-backed currencies and multiple international reserve currencies, and a joining of hands by professionals and Sharī'ah scholars to design a currency system compatible with the Islamic financial system.

\subsection{Money in Islamic Economics, Banking and Finance}

Contemporary jurists and scholars have not done much work on the issue of money and credit creation in the light of Sharī'ah principles. Certain significant efforts (e.g. Khan \& Mirakhor, 1994; Meera \& Larbani, 2009; Hasan, 2008b; and Werner, 2014) have been made to elaborate on the issue and offer recommendations.

The Islamic Fiqh Academy (IFA) (1986) resolved that 'paper money is real money, possessing all characteristics of value, and subject to Shari'a rules governing gold and silver vis-à-vis usury, zakah, salam and all other transactions' (Resolution no. 21). The IFA (2000) recognises the problem of inflation under the fiat monetary system and recommends multiple measures to deal with it. These include proper checks on the quantity of money, a reduction in budgetary deficits and the discouragement of usurious financing by governments, the development of an inflation accounting standard, and the independence of central banks in monetary management.

All fiat monies, in physical paper or electronic form, as well as cryptocurrencies, fall into the category of Al-Nuqood-ul-Istilahiyya (Zulkhibri, 2019). According to Zulkhibri (2019), Shari'ah scholars allow anything used by people as money, including gold, silver, wheat, barley, salt, dates, etc., paper currencies and coins, and electronic money and cryptocurrencies. Paper currency is granted credibility by the government of a country declaring it legal tender. No form of currency can be used as a commodity or a good that could be leased for rent (Hassan, Muneeza, Abubakar, \& Haruna, 2021).

The currency system other than gold and silver was supported by Ahmad ibn Hanbal (d. 241/855), Ibn Hazm (d. 456/1064) and Ibn Taymiyyah (d. 505/1328). Hasan (2008b) argues that price stability, as well as exchange rate stability, is attainable under a fiat money system through proper economic management.

Riazuddin (2011) discussed the issue of money creation and expressed the view that credit/money created out of thin air is riba as a whole, not only the interest on it. He elaborated that the 'principal' created through a book-keeping entry by any central bank seemed clearly to be a kind of excess over nothing and, therefore, a grave injustice and resembling ribā in its essence. 


\subsection{Monetary Policy Objectives and Functions of Monetary Authorities}

Ibn Khaldun found a stable price level with a relatively low cost of living to be preferable, from the point of view of both growth and equity and in comparison with bouts of inflation and deflation. This perspective refers to inflation targeting and 'price stability' as the main goal for a central bank.

Hanif (2020) suggests that in the presence of inherent value limitation under the fiat currency system, multiple jurisdictions are required to have legal tendering legitimacy for the international payment system, necessitating many reserve currencies in multiple economies.

Regarding sharīah-compliant monetary instruments, Riazuddin (2011) suggests that Shariah scholars explore whether central banks could be allowed to invest in any instruments through a simple book entry, as is currently the case with central bank financing of the public sector. He suggested limited permission in case of a clear monetary policy need to hold such instruments in the short run, to the extent of banks' deposits being held by the central bank based on the cash reserve requirement (CRR).

\subsection{Monetary Policy Tools in Islamic Finance and Monetary Management}

According to Iqbal and Khan (2005), financial engineering, as the major tool of creating money and credit, is a process through which risk is partitioned into the smallest possible components, and financial assets are then designed that can best match the micro profile and specific risk-takers on money and financial capital. In Islamic finance, of course, this must be subjected to the principles of the Shariah.

As contended by Riazuddin (2011), jurists must resolve issues regarding the nature of Shariah-compliant tools for monetary management. Regarding the level of public debt held outside the central bank, he suggests that the State may limit its borrowing to the extent of the value of its assets; this would pave the way for the private sector to raise more resources to undertake productive economic activities that promote investment and growth. Of course, the limiting mechanism should be the value of the government's real assets, not the GDP of the economy, as is the case in the conventional interest-based system.

Regarding the benchmark rate of return for Sharī'ah-compliant monetary instruments like sukuk, etc., Riazuddin (2011) suggests that surveys can be conducted to establish the rental value of real estate, buildings, etc. Hence, an 'Office Price Index' and 'Office Rent Index' could be developed to derive profit rates and annual rental rates. He adds that 'transparency of survey methodology and public availability of updated indices every six months would be of paramount importance'. Survey-based techniques may also be used to establish benchmarks for equity-based instruments by estimating profit rates in relevant sectors of the economy.

Regarding reserve currencies for international payments, Hanif (2020) contended that 'a single international reserve currency (with country-specific legal tendering) is subject to the risk of destabilisation across global markets'. Reserve currencies for various regions and cooperating communities (including Asia, Africa and the Organisation of Islamic Cooperation (OIC) countries) would contribute to strengthening the global financial system (Ayub, 2007; Hanif, 2020). 
According to Ayub (2019), an international Shariah-compliant lender/financier of last resort facility is needed, potentially by establishing an Islamic Monetary Fund (IsMF), that could either provide Shariah-compliant liquidity at the global level or coordinate the arranging of liquidity from other central banks. Islamic infrastructure institutions like IDB, IFSB, IIFM, IILM and LM may coordinate to establish such an Islamic Monetary Fund.

One major issue in the context of dealing with money creation and monetary management issues is a shortage of experts holding dual qualifications and experience in Islamic jurisprudence and economics, money and finance. As McMillen (2007) notes, 'While the Shariah is the subject of voluminous scholarship, the Shariah as applied in Islamic finance is largely oral, although there is a growing body of literature and fatawa'. Even jurists associated with IFIs do not go deep with research and development in Islamic finance, and many times they do not even consider any need for such Shariah-based research in monetary tools and management. They deem legal compliance sufficient for Shariah legitimacy (Mansuri, 2021). This is due to a reliance on contract mechanics or compliance with the requirement of a formal contract, ignoring the values and objectives that Shari'ah seeks to realise through its financial system.

Ayub (2015) emphasised the need for a new protocol to solve the problems facing global and also national economies and finance through the adoption of a law aimed at ensuring that 'money could earn return only by way of taking business risk and adding value for the parties concerned. ... Sharīa ah allows incurring debt, but the debt must not become a curse or a tool to enslave the poor.' Ayub (2015) added that this required fresh policy approaches, new structures of finance as a business, new models, procedures and fresh thought to relate money, banking and finance with the real economy.

\section{ECONOMICS FROM AN ISLAMIC PERSPECTIVE}

The above state of development of Islamic economics and finance also requires the development of the economics syllabi used to teach the younger generations. The current paradigm and approach, with its increasing focus on the money form of wealth, leads to economic activities that operate and interact in the market in terms of money only and the objective of the approach is material, not humanistic. Fiat money has no intrinsic value for sale on its own and has no usufruct that makes it suitable to rent. This was the position of Classical economics as fathered by Adam Smith and nurtured by his followers, although Keynesians did not believe it ${ }^{2}$.

The prohibition of riba implies that an Islamic economy does not grant a right to financial resources (monetary assets) to claim a fixed rent. This constitutes a fundamental difference between the conventional and Islamic macro models. It also suggests that monetary economics and monetary policy can be studied from an Islamic perspective to understand the following three questions.

\footnotetext{
2 For Smith's views on money, see: Nicholas A. Curott (2016); Adam Smith's Theory of Money and Banking; Studies in Applied Economics; SAE. /No.47/February; Johns Hopkins Institute for Applied Economics, Global Health, and Study of Business Enterprise.
} 
a) What would be the economic model of Muslim countries when their economies can become (or are assumed to be) Islamic economies free of the interest-based financial system?

b) If Muslim economies have only partially introduced an Islamic banking and financial system, how can this practice be considered Islamic in the real sense?

c) What type of Islamic banking and financial system would fulfil the real spirit of an Islamic economic system and what monetary policy and macroeconomic framework would be used in such a financial system of a Muslim economy?

The current state of Muslim economies is far from describing monetary policy and monetary economics in a meaningful way according to the assumptions of (a) and (b) described above. This would require economies to be operating in the situations described in (a) and (c). A meaningful discussion on monetary economics and monetary policy can be held with respect to contemporary Muslim economies as described in (b) above. Stagflation in the world economy in the 1970s and later, the unprecedented financial crises since 2007-08 have led world economists to rethink their approach to monetary economics and monetary policy.

\subsection{Model for an Islamic Economy}

Since the Classical model is conceptually more relevant to describe a Muslim economy, let us explain how a Muslim economy can be seen through the lens of Classical theory before we discuss the monetary system from an Islamic perspective.

Keynes' book 'General Theory' appeared in 1936 and described macroeconomic concepts by explaining that unemployment occurred as a result of a failure of (the real sector) market to self-clear itself. This was attributed to the money market, which required monetary policy to increase income and employment. This in turn required the central bank to regulate credit creation through borrowing and lending by commercial banks. Monetary policy was needed to manage growth and the stability of the economy.

Economics, from Adam Smith to the present day, exists only as the economics of the market. Adam Smith, Alfred Marshal and other followers all based their theory of economics on the assumption that economic activity is the only thing that exists in the market. Hence, conventionally, all economies are called market economies. The market is assumed to perform at its best when the sanctity of private property is assured in society and the exchange of property rights is protected. From an Islamic point of view, this concept of the market and its significance is not new. The sanctity of private property rights and rules of free exchange, and thus the significance of the market, formed a prominent part of the Islamic system of life, as laid down in the Qur'an and Sunnah, more than 1000 years before Adam Smith recognised it. Of course, an Islamic economy cannot merely be considered a market economy if it is to be described as an Islamic model. Let us therefore note the prominent features of an Islamic system that would distinguish an Islamic economy from one assumed under the Classical model.

1. The market will play a predominant role in an Islamic economy, but it will not be a capitalist economy because of its other features. 
2. The market will be governed by strict laws to ensure the sanctity of property rights and the exchange of property rights as laid down in Islamic commercial law. These laws will make the market perfectly competitive, which is meant to make the market self-clearing.

3. Interest does not exist in an Islamic economy as a time value of money. The economy, therefore, will lose the opportunity to make speculative gains by holding money. To this extent, it will be like the Classical model in the sense that it can have only a real market.

4. Money will not receive a fixed return, either in lending or in so-called investment. If the holders of money wish to use money for productive return, then it must be used as an investment to earn profit/bear loss based on whatever it produces. This constitutes a clear denial of the Keynesian theory of economics.

5. Unlike the conventional economy, whether Classical or Keynesian, capital will not earn a fixed return irrespective of whether entrepreneurs gain or lose. Interest does not exist in the economy, either as a determinant of investment or as a basis of the reward for the productivity of capital.

6. A money market either does not exist at all because money demand for speculative purposes is unlikely to exist, or, if it does exist despite the absence of interest on savings or loans, it cannot affect the real market in the way assumed in the Classical model.

7. In an Islamic economy, economic activities exist beyond the market, which is a significant aspect of this type of economy. This is a unique feature that does not exist in any conventional theory. The basis of this activity is what we call infaq fi sabeelillah (IFS-spending in the way of Allah). A minimum level of such spending or donation is obligatory and is called zakah and ushr, given to help neighbours and relatives or just provide charity to anyone or for any reason, meant only for the sake of Divine pleasure and rewards in the life Hereafter.

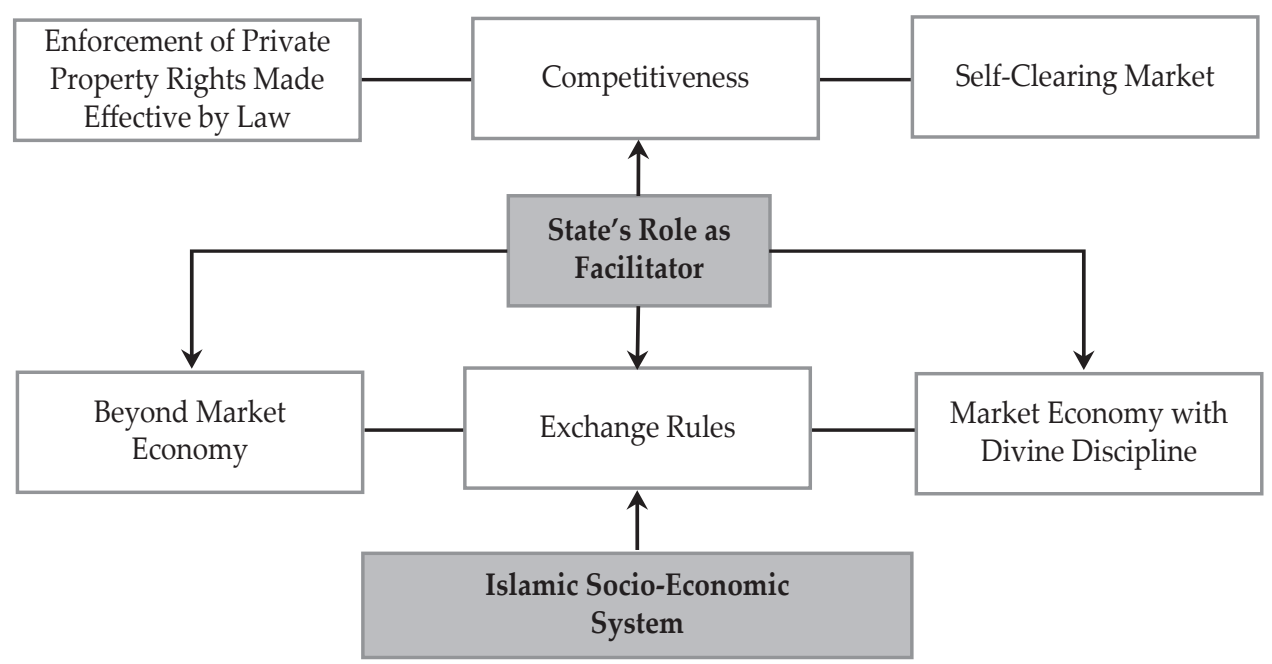

Figure 1.

Prominent Features of the Islamic Socio-Economic System 
Infaq fi sabeelillah (IFS) is spending in the way of Allah which as a concept suffered no loss of significance even during the period of colonial rule. IFS needs to be considered as a transfer of resources. Islamic history has proved that this (IFS) has been used as an economic activity for improving the economic status of the poor and making them contribute to the addition of value in the economy. The ways in which IFS has been used include the creation of educational institutions, hospitals, water channels and various other activities, enabling the poor to earn rather than depend permanently on charities.

\subsection{Features of an Islamic Economy}

In the absence of an Islamic model, formally recognised in either the contemporary Muslim world or in the early history of Islam, we can only demonstrate that such a structure would have the following features, based on the economic teachings of the Qur'an and Sunnah. These features will then be used to describe the macroeconomic framework and hence monetary policy for an Islamic economy.

a. Markets are perfectly competitive, which thereby makes them 'self-clearing'. In Classical theory, this is just an assumption, but for the Islamic economy it results from the application of Islamic laws to market operations.

b. Islamic history does not provide any significant evidence to justify that there was, at any point in time, either money illusion or that people held money for speculative purposes. While people may like to hold some money for specific transactions or keep some in hand for urgent needs, such demands cannot lead to the creation of a money market in the economy; hence, the market economy, other things remaining the same, will always remain a 'real market economy' irrespective of the role of money in the market. Even if money demand existed, it is very unlikely that an economy run under Islamic principles, in the absence of interest rates on loans and rules of market transactions, would allow money to earn a fixed rate of return and hence create a money market that would substantially affect the real market.

c. Economic activity does not exist merely in the market, but also beyond the market as an integral part of the system. The Qur'anic injunctions state that the have-nots have a right to share in the wealth of the haves (Qur'an 51:19 and 70:24).

d. Savings will be equal to investments and there will be no leakage in the economy that creates inequality between saving and investment.

e. In the market, economic activities primarily make the economy grow by maximising the economic gains realised from those activities. In contrast, beyond-the-market economic activities primarily lead to an economy in which the prosperity achieved by the market is shared with those unable to gain from market activities.

f. The aspects of economy created by Islamic laws on market operations imply the following main features, assuming the laws are properly implemented.

i. Perfect information about products: In Islamic law, sellers are required to provide everything that they know about the products. Information asymmetry and moral hazard are minimised. Information cost, transaction cost created by contractual activities for exchange and other costs that can 
create market failure may also be minimised by creating an appropriate institutional framework in the economy.

ii. There is freedom of entry into and exit from the market: It is forbidden to meet a supplier of goods outside the market as this would deprive sellers of the opportunity to face the entire set of potential buyers.

iii. It is prohibited to conduct economic activities in the market aimed at acquiring market power. Hence, monopoly, monopolistic competition, hoarding etc. are prohibited as these structures deprive buyers of the ability to negotiate with the full variety of sellers or suppliers.

iv. Transaction cost is minimised through proper documentation and the enforcement of all provisions of market operations involved in delayed payment or delayed delivery of exchange.

These features make the market efficient in terms of increasing national wealth. The beyond-market activities become not only a source of economic justice and social harmony but also help to raise the economic status of even those unable to increase their market status. There is an implication that markets will always be in equilibrium and self-clearing in the event of any shock that moves them away from equilibrium. Neither the market aspect nor beyond-the-market assets will be affected by the money market. The economy is real; as such, interest, and hence a market for speculation, will not exist. Therefore, equilibrium is determined by real variables. The unique feature of this model is that efficiency and equity exist simultaneously in the economy.

We next discuss monetary economics in two scenarios: discussion in the framework of an Islamic economy to draw lessons only in theory, and discussion about present-day Muslim countries where Islamic banking is being practised. Of course, it would be a futile exercise to develop monetary economics for any present-day Muslim country, considering a model of a truly Islamic economy.

\section{MONETARY ECONOMICS IN THE ISLAMIC FRAMEWORK}

The monetary sector in a truly Islamic economy will have money supply (MS) and money demand (MD), both determined exogenously. MS is determined by the monetary authority (in consultation with a board of economists and Sharīah scholars). MD, meanwhile, will be determined by households on the basis of several exogenous factors. The monetary sector will require a balance. Households need to maintain a balance in terms of holding money for the purpose of meeting pure timely needs and for investment purposes. Monetary authorities need to maintain a balance in growth and inflation in the economy to determine the money supply.

\subsection{Demand for Money in an Islamic Economy}

Demand for money for the love of it is considered a matter of mindset. Reflecting this, the mindset created under Islamic rules does not align with the mindset implicit in the Keynesian approach. It is therefore assumed that from the Islamic perspective, money is demanded only as a medium of exchange and has no value of its own. There is no money illusion in the mindset of a Muslim. On the contrary, the admonition in the Qur'an, 'And those who hoard gold and silver and spend it 
not in the way of Allah - give them tidings of a painful punishment' (9:34), serves as a discouragement to hold and accumulate money for its own sake. We therefore define demand as the set of (liquid) assets that are readily available for households to buy goods and services or to avail investment opportunities or to give away to seek Divine pleasure.

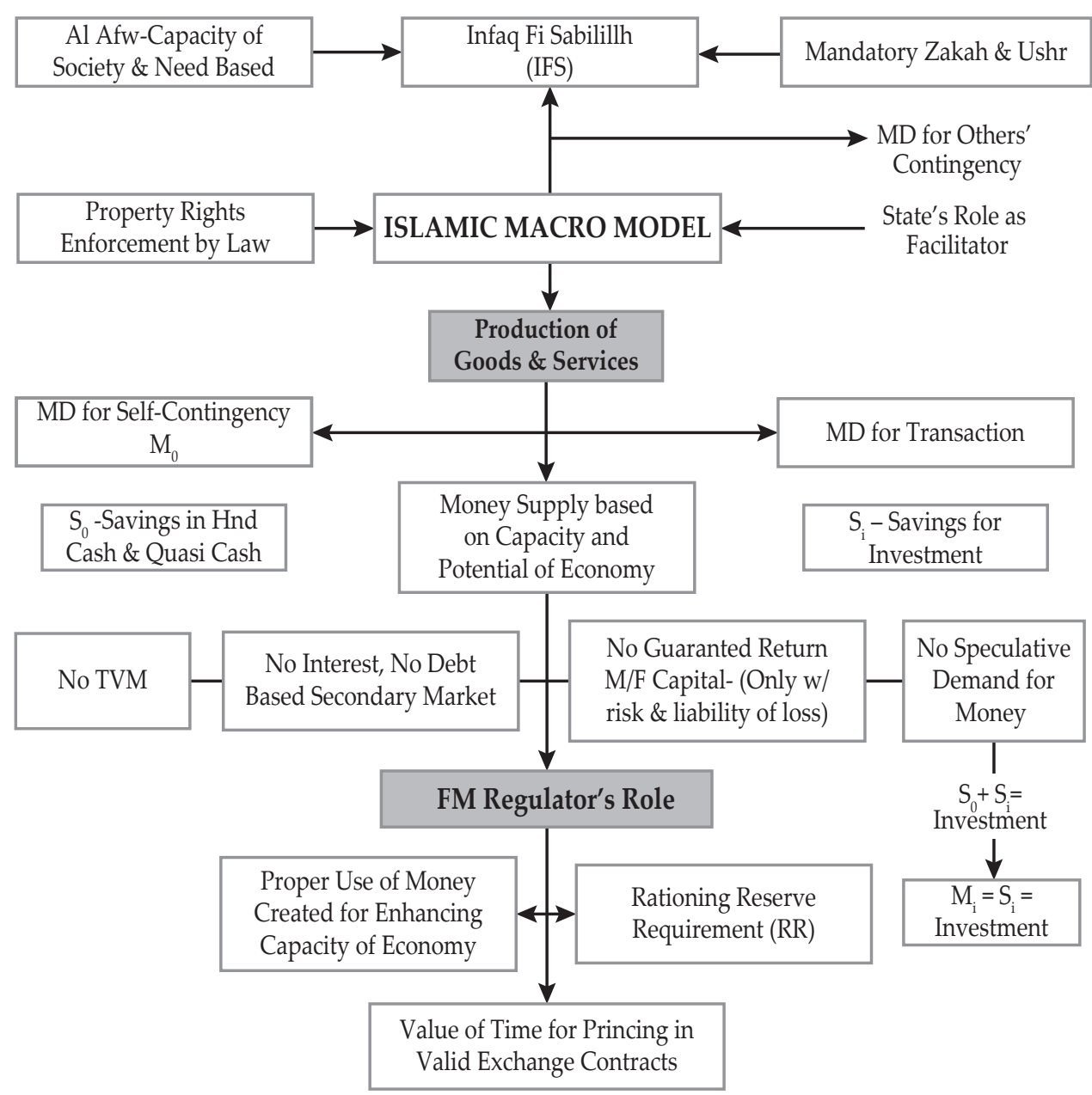

Note: FM = Financial Market; MD = Money Demand; $\mathrm{So}=$ Savings in Hand; $\mathrm{Si}=$ Savings for Investment; $\mathrm{Mo}=\mathrm{MD}$ (Money in Hand); Mi = Investment Demand; TVM = Time Value of Money

Figure 2.

The Framework of Islamic Monetary Economics

Money demand affects aggregate demand and hence becomes relevant in terms of it having a role in monetary policy. Demand for money in an Islamic economy will be a stable function of variables such as income, price level and the rate of return on investment [excluding investment in mere financial assets]. 
Money in the hands of a Muslim has two components:

a) For pure time preference: Just to meet the needs of daily transactions, for precautionary needs or to meet demand to help friends and relatives. This demand may depend on several factors, all exogenous.

b) For investing to make more money from it. Although this has to be very short-term investment and in such a way that it can be liquidated to meet the expected needs.

Money Demand will thus be: $\mathrm{Md}=\mathrm{M} 0+\mathrm{Mi}$; where $\mathrm{M} 0$ is money demand for pure time preference and $\mathrm{Mi}$ is money available for short-term investment.

However, this is only one side of the coin. The other side is household savings, which also has two components: $\mathrm{S}=\mathrm{S} 0+\mathrm{Si}$; where $\mathrm{S}_{0}$ is a household's savings they want to keep liquid for normal transactions and unforeseen needs; $\mathrm{Si}$ is savings destined for long-term investment ${ }^{3}$.

The saving function in the economy would thus be:

$$
S=S(Y, i) \text { or } S=S 0+a . Y+b . i
$$

where ' $\mathrm{Y}$ ' is national income and ' $\mathrm{i}$ ' is the rate of return on saving. The investment function in the economy would be:

$$
\mathrm{I}=\mathrm{I}(\mathrm{Y}, \mathrm{i}) \text { or } \mathrm{I}=\mathrm{I} 0+\mathrm{c} . \mathrm{Y}-\mathrm{d} . \mathrm{i}
$$

where ' $\mathrm{Y}$ ' is national income and ' $\mathrm{i}$ ' is the rate of return on investment.

We cannot go into details regarding the savings function, investment function and equilibrium conditions in the real sector as this would require a whole macro model to be specified and discussed. In economics from an Islamic perspective, we do not like to talk of equilibrium and equilibrium conditions. This is because equilibrium refers only to market-led economics. In an Islamic economy, there is a lot of economics beyond the market where equilibrium makes no sense and we can only try to ensure economic balance in the country.

Demand for money in an Islamic economy, therefore, will be part of the real sector. This will be determined endogenously. For the time being, to keep the analysis simple, an Islamic economy is assumed theoretically to have no opportunity for investment, whether in the short or long run, that (a) can keep the principal amount intact, (b) can be liquidated immediately on demand, and (c) can still yield some return.

Households will only keep an exogenously determined amount in hand for the purpose of meeting their own contingencies and the contingencies of others (e.g. neighbours, relatives and friends) in the way of Allah. This will be Mo as explained above and will not form part of the money market. The other part of money demand will be only to avail investment opportunities. This money demand will be part of the real sector and not of the money market.

\footnotetext{
3 Note: Here, we have avoided discussing specific macroeconomic variables and equations for an Islamic economy. We just keep in mind that the macroeconomic variables will be aggregate values of income $(\mathrm{Y})$, consumption $(\mathrm{C})$, savings $(\mathrm{S})$ and investment $(\mathrm{I})$, and there will be no interest, but the market will not be short of some benchmark rate of return (i) on capital.
} 
It is here that the Islamic macro model will differ from the Classical model. The Classical model assumes that savings will equal investments. They assume that nothing is leaked out of savings and that everything goes to investment. Under the Islamic macro model, we assume that part of savings will be held in hand in a liquid or quasi liquid form called S0, and Si will be part of the real sector and will be equal to investment. Thus, assumption No. 4 for this section will be $\mathrm{Mi}=\mathrm{Si}=$ Investment. Si is investment demand and not money demand, while M0 is money demand.

The actual proposition of demand for money, however, will be a matter of empirical testing when an 'Islamic' economy comes into existence. It is possible that empirical evidence may show money demand to be endogenously determined, and if this is the case, then absolutely a new macroeconomic theory and model will need to be developed. However, until this happens, we will assume that the theoretical scenario mentioned above for discussing monetary economics and drawing lessons for monetary policy will be valid in an Islamic economy.

Before discussing the monetary policy, it is important to understand the cost of holding money from an Islamic perspective.

\subsection{Cost (Price) of Holding Money from an Islamic Perspective}

Here we consider the following issues: What cost other than the interest rate will households keep in mind while holding money in hand? What alternative options will be available for households to invest their liquidity in a short-run, risk-free return when the country does not have the option of investment in interest-based products? This is basically an empirical question. The market would come up with alternatives for earning a return on short-run investments. However, a problem arises when we consider what to do when a Muslim country is gradually moving towards transforming its financial system. For some time, the economy will run a dual system, partly Islamic and partly interest-based. In such an economy, households have opportunities to earn income on their short-run investments in an interest-based money market, but there is no way out for those who do not seek to avail of these opportunities. As the proportion of such households increases in an economy, the open market operations for controlling money demand will become less and less effective.

The issue is thus to develop a market for short-run investments that can be quickly liquidated when needed. The central bank needs to allow products yielding a Sharīah-compatible rate of return that are easily negotiable in the secondary market.

Free markets in the Muslim world cannot be short of opportunities to absorb short-term investment in the real sector with almost no risk of this becoming the basis of an Islamic money market. It is only a matter of institutional arrangement to develop financial instruments for an Islamic money market that offer opportunities for short-run investment, with minimal or almost no risk. The following types of financial products could thus be developed for such a market.

a) Debt-based instruments on the short-term credit sale of commodities carrying a fixed mark-up rate;

b) Bai-salam-based products; and

c) Profit/loss-sharing instruments. 
Short-term debt-based instruments can be generated in the commodity market and would carry a fixed mark-up rate. However, Sharī'ah restrictions would prevent these from being negotiated in a secondary market on a discount basis. Yet some institutional arrangements could permit the holder to liquidate the instruments readily at face value. Short-term profit/loss-sharing instruments could be generated in both the commodity and equity market. Commodity tradebased (profit/loss-based) sharing instruments may be preferable to those on the equity market unless proper Islamic rules and laws are implemented to prevent the market from manipulating stocks. These profit/loss-based instruments would be negotiable in the secondary market.

A Muslim country with a dual system could decide to announce an expected profit rate (instead of interest rate). Let us call this $\mathrm{R}$. It should be possible for the government to make all its purchases against the issuance of fixed markup-based securities, although the proceeds from such securities may not become part of the public debt system in general. The government can issue profit/loss sharingbased short-term securities and it should not be difficult to issue such certificates that carry an expected profit rate with a guarantee of a narrow range variation. Government can also issue qard-al-hassan securities and sukuk redeemable on demand to absorb the money demand in the Islamic money market. The central bank or monetary authority, in consultation with any competent advisory board comprising Sharī'ah scholars and economists, can announce the mark-up rate and expected profit rate for Islamic financial institutions involved in goods trading and for the government securities.

\subsection{Monetary Policy in an Islamic Economy}

Since money acts purely as a medium of exchange, it would simply affect the price level, while the real income/output, the real wage and the real rate of return on capital in the economy would remain unaltered with a change in money supply.

According to the classical 'Quantity Theory of Money', the price level has the following relationship with the money supply:

$$
\mathrm{MV}=\mathrm{PT} \text { (Fisher's Equation) }
$$

$$
\begin{array}{lll}
\text { where } & \text { M=Money supply; } & \text { V=Velocity of money } \\
\text { P=Price level, and } & \text { T=Real total output (transactions). }
\end{array}
$$

Put simply, a change in the money supply $(\mathrm{M})$ results in a proportional change in the price level $(\mathrm{P}), \mathrm{I}^{\prime}$ ' and ' $\mathrm{T}$ ' remaining constant.

Monetary policy within an Islamic framework would only entail deciding the optimal level of money supply required to meet the desired inflation rate and growth targets for the economy. The exercise of determining the level of money supply should therefore be a central bank decision taken in consultation with an 'advisory board' as suggested above, who would advise keeping in view the economic and Sharī'ah objectives for the economy. As liquidity increases, households would simply spend, invest or give money away in the way of Allah, and hence increase the demand for goods and services. This in turn will raise the price level. Real wages and real rental on capital goods will fall, hence providing incentives to employ more labour and capital to produce more goods and services. 
A financial system may exist in an Islamic economy that allows credit creation and financing for investment as well as consumption. In principle, it would be based on the availability of goods and services that are usable by human beings, and their potential growth in the future. The latter part would be determined under the principles of bai al salam and the purchase of non-ribawi fungible goods ${ }^{4}$, as provided in Islamic law of contracts. Only empirical evidence is capable of proving how this would happen in practice.

\subsection{Equilibrium in the Money Market}

Since money demand is negatively related to the cost of holding money (i.e. some rate of return on investment), the result is a downward-sloping function with respect to this cost of holding money. With the supply of money fixed by the government, there will be a money market to determine the equilibrium amount of money held by households and ' $r$ ', which is the cost that households are willing to bear for holding this amount.

This ' $r$ ' will increase whenever the money demand from households shifts up or the money supply is reduced by the central bank. When ' $r$ ' goes down, investment goes up, as discussed earlier. An increase in ' $r$ ' will increase investment, which will increase aggregate demand and hence lead to an increase in output. The higher the rate of return on investment, the lower will be the demand for money, and vice versa. This negative relationship between the demand for money and the rate of return on investment provides a link between changes in the money and real sector growth.

\subsection{Credit Creation in a Muslim Economy}

For countries attempting to change their financial and monetary system to bring it in line with an Islamic system, a question arises: if credit creation continues to exist, what should the monetary policy be that allows the economy to realise the objective of eliminating interest from the system? The system allows banks to lend money that they do not have. This, in principle, is a crime in Sharī' ah and creates moral hazard. In addition, for Islamic banks, it creates information cost and transaction cost. This cost is more for Islamic banks than interest-based banks.

Sharī'ah scholars have not yet considered this issue and given any verdict against credit creation, although Islamic economists have discussed it in academic circles. However, a conclusive opinion as to whether Islamic banks should or should not create credit has not yet been reached. The discussion is mostly confined to the moral aspects of reserve requirements, and hence discussion of a $100 \%$ reserve requirement. However, central banks allow Islamic banks to create credit in the same way that conventional banks do. The issue that needs to be resolved is thus: what monetary policy tools would exist to regulate credit creation

\footnotetext{
${ }^{4}$ Ribawi goods are items whose exchange may involve riba, as in the well-known hadith of the exchange of six goods, including gold, silver (modern forms of currencies included) and edible goods like wheat, rice, barley, dates, salt. Salam is not allowed in such items that have to be exchanged hand to hand.
} 
by Islamic banks when the macroeconomic objectives require an expansion or contraction in credit?

\section{MONEY AND MONETARY POLICY IN PRESENT-DAY MUSLIM ECONOMIES}

In present-day Muslim countries, central banks depend on the interest rate as the kingpin of monetary regulation and policy for managing the economy. The question concerns the approach that we should take towards monetary economics in a Muslim country which is not yet really 'Islamic' in the sense as explained earlier, and has only begun to partially introduce the notion of interest-free within the financial system as a starting point in the process of complete transformation.

Money demand in Muslim countries will mainly be for transactions, keeping money in hand for daily household needs. This demand for money will not be affected by the interest rate but may understandably have a positive relationship with income. There is, thus, no sufficient empirical evidence to disallow the Classical or Neoclassical model over the Keynesian model for present-day Muslim countries. However, there are several theoretical arguments to assume that the Classical model will be more relevant for monetary policy in present-day Muslim countries, albeit with some adjustments to reflect certain peculiarities of Islamic principles.

Liquidity is preferred in the Keynesian framework for various reasons. Assume that households have liquidity preference and money demand is a function of the interest rate. If these economies were to move towards an Islamic financial system in a gradual way, then the question would arise of how to estimate money demand. People who practise Islamic finance cannot use the interest-based money market to manage demand. Such countries therefore face several issues, as discussed below, with respect to their monetary system, which has proven to be a serious barrier on the path to transformation.

First, households that do not wish to manage their financial matters on an interest basis have no formal opportunities for managing their liquidity. As a result, they keep a large amount of liquidity in informal channels. They may use this for short-term investment but only through informal channels or else keep excessive liquidity beyond their preference. The issue, therefore, is how to bring this liquidity into the money market so that people reveal their true liquidity preference. Second, there are financial institutions in these countries that operate on the basis of interest, and there are households that do not mind investing their liquidity with interest-based institutions for reasons of convenience or otherwise. The presence of interest-based financial institutions means that the pricing of Islamic products is not determined in the real market. Instead, the interest rate in the economy becomes the benchmark for pricing products of the Islamic financial market. Third, the central bank is obliged to use the interest rate to manage interbank lending and borrowing because neither the central bank nor commercial banks have Islamic financial products to accommodate each other's short-term financial needs. Money demand will thus continue to depend on the interest rate while a substantial part of this demand will remain in the informal channels. 
Money supply is generated by two sources. Central banks produce highpowered money by printing currency, while the banking system creates credit. Up to now, Islamic scholars have raised no specific objection regarding the process of credit creation. A monetary policy is, of course, needed to regulate the money supply. Central banks can curtail the money-creating powers of the banking system through their reserve requirements. If the central bank requires a 100 per cent RR, the banking system will not be able to create any credit or increase the money supply at its discretion. But presently, banks can create almost as much credit as they want, provided that the economy can sustain the profitability of the banking system and their actions do not land the banking system in trouble by causing a run on the banks.

Islamic economic principles do not favour investment through debt or credit creation. In present-day Muslim economies, the first step should have been to gradually curtail the powers of the banking system to create credit at their discretion. The money supply needs of the economy should then be gradually assumed by the central bank through printing and issuing currency based on the potential of the economy.

Changing the supply of money can effectively change real variables like employment, output and income by influencing aggregate demand. The effect on output will depend on the elasticity of supply of the aggregate output. If there is excess capacity in the economy, an increase in the supply of money will increase investment by raising the return on capital. This in turn will raise effective demand through the multiplier effect, thereby increasing income, output and employment.

Unless the rate of return is too low in a Muslim economy, the money demand curve will remain downward-sloping if the Keynesian hypothesis of liquidity preference is considered, and there will remain a need for monetary policy. No Muslim countries, particularly those that are introducing Islamic finance, have a rate of return on investment too low to imply infinitely inelastic demand for money to the point that monetary policy becomes redundant. If the Keynesian hypothesis holds true in present-day Muslim economies that households do have liquidity preference, even without any love for money for its own sake, then monetary policy will continue to be needed. Though the original Keynesian view, that money supply can affect output, went through several transformations and they no longer believe that monetary policy can affect employment and output, New Keynesian advocates continue to use monetary policy for other macroeconomic objectives such as stability, if not for employment or output. The need for monetary policy is also now being emphasised to offset the effects of unexpected external shocks to the economy. However, the question is what monetary policy tools are needed for the interim period until the transformation is completed. Continuing to use the interest rate as a policy tool would be counter-productive to any effort aimed at creating a Sharī' ah-compliant Islamic financial and monetary system.

In the background of the above discussion, if the interest rate or its equivalent is present within the economy, let us examine the options available in presentday Muslim countries for moving towards a transformation of their financial and monetary systems to conform to Sharī'ah. The following policy directions are suggested: 
a) Rationalising reserve requirements and the utilisation of credit created through it; and

b) Replacing secondary market debt-based instruments with profit/loss sharingbased instruments.

\subsection{Rationalising Reserve Requirements and Utilisation of Created Credit}

Economists thinking from an Islamic perspective have always questioned the Sharī'ah justification in two respects:

- Why should credit creation by the banking system continue to be a source of money supply when government has the sole authority to change money supply by its power to print money?

- Why can credit so created not be used productively without allowing it to become inflationary?

Economists provide no rationale for permitting the banking system to do this despite the negative implications for efficiency, stability and equity in the economy. Loaning through the creation of credit by the banking system enables as much money as they want to flow to the rich, encouraging the richer to shift towards high-risk activities and hence making the economy inefficient. The current economic scenario has shown, overwhelmingly, that credit and loans are not only being acquired unfairly but are also being used in economically inefficient activities such as gambling and investment in junk bonds, etc. While the Japanese tend to save a lot and spend little, Americans, in contrast, spend a lot and save little. Also, the US imports more than it exports; in 2019, its trade deficit was \$576.9 billion. Yet the American economy is considered strong and is also trusted to grow stronger. Against this, Japan had an annual trade surplus of over US $\$ 100$ billion. Yet the Japanese economy is considered weak, even collapsing. Global savings are mostly invested in the US, in dollars. The same scenario is seen in national economies, where wealth is transferred to the financial sector at the cost of the real sector - those who create goods and services for use by human beings. The whole concept of development and welfare has been corrupted; 'Saving is sin and spending is virtue.'

This irrational economic situation is occurring as a result of two undesirable factors within world economic phenomena. First, aggregate consumption is being raised through loans and credit, which is pushing the propensity to consume towards unity. However, loans are granted and credit created based on savings deposited in banks and other financial institutions. Second, to enable investment and hence allow the economy to grow and achieve the desired economic progress, the poor must save sufficient amounts. However, this encourages the financial system to create credit and grant loans; in other words, to do nothing except make the economy bankrupt. This paradox of the world is compelling economists to believe that a nation cannot grow unless people spend; not just spend, but borrow and spend; and this cannot happen unless borrowing continues to grow through credit creation.

It is the creation of credit from the savings of the poor that is enabling rich people to increase their luxurious and wasteful consumption to create the problem. A monetary policy based on an Islamic perspective can enable Muslim countries to escape this plight and requires making the banking system truly Islamic. 
The starting point for creating a monetary policy with respect to credit creation by banks should be:

- Not to allow credit created to go to high-risk (gambling-type) consumption or investment; and

- To increase aggregate consumption for economic growth by directing credit creation to the poor to enable them to fulfil their consumption needs and for entrepreneurship.

In addition, monetary policy should directly or indirectly aim at encouraging increased spending in the way of Allah as the teachings of the Qur'an and Sunnah require people to help the poor and needy through formally organised channels. A properly developed system of awqaf can bring greater economic efficiency, stability and social harmony along with economic growth in the same way that credit creation by the banking system is intended to realise.

\subsection{Replacing Debt-based Instruments with P/L Sharing-based Instruments}

Sharī'ah scholars in the contemporary Muslim world have suggested a variety of financial instruments to suit the needs of every person, which cannot be called riba-based financial instruments. The rates of return on these instruments relate to the real market and not the money market. Currently, these instruments take the form of debt-creating and profit/loss-sharing instruments and can meet the riskreturn profile of every person in the economy. These instruments are asset-backed and are not merely monetary instruments. The following need to be taken care of with respect to formulating monetary policy from an Islamic perspective:

The first step is that Muslim countries (that are introducing an Islamic financial system) may legally prohibit 'interest' as being riba and consider replacing the 'interest rate' with a mark-up or profit rate. This would prepare people mentally both at home and abroad to accept the modalities of when a mark-up or profit rate refers to the rate determined by the real market and not the money market. It will also make people conscious of investigating the details of their financial contracts when using a mark-up or profit rate for the basis of their financial dealings.

Second, irrespective of whether the term 'mark-up' or 'rate of profit' is used instead of 'interest rate', it should be the rate that the central bank announces as the bank rate, benchmark rate, interbank rate or discount rate. The rate will be determined based on data from the real commodity market, real assets rental market or equity market. Actual profits and mark-up determined from the real market would be applicable in the interest-based financial and monetary market running parallel to the Islamic financial and monetary market. The central bank would declare the mark-up or profit rate determined from the real market instead of announcing the interest rate for interbank transactions.

\section{CONCLUSION AND RECOMMENDATIONS}

\subsection{Conclusion}

Islamic economics could be taken as a real alternative to conventional economics if it could be introduced in a distinct way. The 2008 crisis became the final nail in the coffin for the current economic paradigm. At that point, for all academic and 
application purposes, conventional economics became conceptually dead. The world has been desperately searching for an alternative paradigm ever since, but Islamic economics has not yet been able to create any impact on current economic thought. The economic paradigm based on the 'creation of wealth' has to be practically replaced by the Islamic paradigm. This too will 'create wealth' but will also come with humane and moral considerations like the creation of peace and harmony, along with economic growth and stability.

Monetary policy issues would have been discussed meaningfully if we had already seen the implementation of this Islamic economic paradigm by Islamic banking and financial institutions. However, the current form of Islamic banking and finance has failed to create any impact in the name of Islamic economics. Had we been able to demonstrate the economic principles of Islam for conducting economic activities beyond the market, to reflect humane and moral considerations while also 'creating wealth' from the institution of the market, we would have been in a better position to engage in a productive discussion on monetary policy issues.

Having said this, we are not discussing 'monetary issues in Islamic economics' but instead, we are presenting 'monetary economics and monetary policy issues for contemporary Muslim countries' that are trying to make their economies 'Islamic'.

If we make the assumption that implementing an Islamic system of property rights and Islamic laws of exchange of property rights reflects the economies of present-day Muslim countries, then understanding monetary economics and hence identifying the issues and discussing their solutions will be simple, without posing any big challenge. Under this assumption, the discussion would have been similar to that contained in the economic literature under the Classical theory. Under this theory, the monetary sector does not affect the real sector and there will be no significant monetary issues. But we cannot assume this for any contemporary Muslim country. We cannot even define a Classical macroeconomic model for a Muslim country. Instead, influenced by Keynesian thought, all economies have assigned 'interest' a central role within their economic management.

\subsection{Recommendations}

Since almost all major Islamic countries are in the process of introducing an Islamic finance and monetary system, we have discussed ways of managing the monetary sector in their economies so that they can gradually eliminate the role of 'interest' while continuing to effectively manage the monetary sector for growth, equity, social harmony and stability in the economy. Based on this perspective, we propose the following steps:

a) Reduce the dependence of the private sector on debt-based investment and allow the economy to grow using profit/loss sharing-based financing.

b) Eliminate the secondary market of debt-based instruments, whether the debt is interest- or markup-based.

As regards reducing financing to the private sector, presently all Islamic banking activities mostly use the concept of mark-up for financial accommodation in giving or receiving financing, observing Shari' ah rules only in letter rather than in spirit, or in form rather than in substance. In this respect, we have two 
suggestions to be discussed with respect to central bank functions so that there is an impact on the economy in terms of achieving the desired objectives of growth and stability with equity and peace in the society:

i) The central bank can determine the mark-up rate or profit rate, whatever they like, to distinguish it from the interest rate and based on actual market transactions in trading or selling and buying over short-term future payments. The market for goods and services should determine the rates to be used in monetary policy.

ii) A strategy for rationalising reserve requirements with the objective that these are essential for creating sufficient credit to achieve Sharī'ah-approved macroeconomic objectives. The credit creation that results from such reserves should be conducted in a planned way to help fund the poor sections of society, micro businesses and SMEs to improve their economic status and not be used for luxurious consumption and wasteful activities.

Regarding the rationalisation of secondary markets, monetary policy in an Islamic framework should consciously eliminate the debt-based securities market and a secondary market should exist only for PLS-based instruments. Monetary authorities should aim to slowly reduce the debt content of investments and design effective policies to ensure the monetary and financial system fully conforms to Sharīàn.

\section{REFERENCES}

Abdullah, A. (2016). An Islamic monetary theory of value and equation of exchange: Evidence from Egypt (696-1517). Humanomics, 32(2), 121-150.

Ayub, M. (2007). Understanding Islamic finance. London, UK: John Wiley and Sons.

Ayub, M. (2015). Financial inclusion: Social inclusion has to be the target. Journal of Islamic Business and Management, 5(1), 05-16.

Ayub, M. (2019). Making Islamic finance a vehicle for social inclusion: A case for revisiting the liquidity management practices by Islamic banks. In Ali, A. E. S., Ali, K. M., \& Khaleequzzaman, M. (Eds.), Enhancing financial inclusion through Islamic finance (Vol. 1). Switzerland: Springer Nature Switzerland. ISBN:978-3030-39934-4.

Chapra, M. U. (2008). Innovation and authenticity in Islamic finance. Paper presented at the Eighth Harvard University Forum on Islamic Finance on Innovation and Authenticity.

Curott, N. A. (2016). Adam Smith's theory of money and banking. Studies in Applied Economics, 47, Johns Hopkins Institute for Applied Economics, Global Health, and Study of Business Enterprise.

Gómez, P. (2020). The wealth of nations in the 21st century. Madrid, Spain: Editorial Círculo Rojo.

Hasan, Z. (2008a). Credit creation and control: An unresolved issue in Islamic banking. International Journal of Islamic and Middle Eastern Finance and Management, 1(1), 69-81.

Hasan, Z. (2008b). Ensuring exchange rate stability: Is return to gold (Dinar) possible. Journal of King Abdulaziz University: Islamic Economics, 21(1), 1-21. 
Hasan, Z. (2011). Money creation and control from Islamic perspective. Journal of Islamic Business and Management, 1(1), 49-68.

Hassan, M. K., Muneeza, A., Abubakar, M., \& Haruna, M. A. (2021). Application of precious metal backed cryptocurrency in Islamic finance. Journal of Islamic Finance Accountancy, 5(1), 17-26.

Hussain, M., Shahmoradi, A., \& Turk, R. (2015). An overview of Islamic finance. IMF Working Paper, WP/15/120.

IFA (Islamic Fiqh Academy) (1986). Shari'ah rules governing paper money. Resolution \#21, Third Session (11-16 October), Jeddah.

IFA (2000). On inflation and change of currency value. Resolution \#115, Twelfth Session (23- 28 September), Islamic Fiqh Academy, Jeddah.

Iqbal, M., \& Khan, T. (2005). Financial engineering and Islamic contracts. London, UK: Palgrave Macmillan.

Khan, M., \& Mirakhor, A. (1994). Monetary management in an Islamic economy. Journal of King Abdulaziz University: Islamic Economics, 6, 3-21.

Mansuri, M. T. (2021). Maqāṣid al Shari'ah: A valid paradigm for Shari'ah opinions in Islamic finance. Journal of Islamic Finance Accountancy, 5(1), 40-53.

McMillen, M. J. T. (2007). Shari'ah-compliant project finance: An overview, including structures. Journal of Islamic Economics, Banking and Finance, 3(1), 1-45.

Meera, A. K. M., \& Larbani, M. (2009). Ownership effects of fractional reserve banking: An Islamic perspective. Humanomics, 25(2), 101-116.

Refinitiv and Islamic Corporation for the Development of the Private Sector (ICD), IDB Jeddah (2020). Islamic finance development report 2020. Retrieved from https://icd-ps.org/uploads/files/ICD-Refinitiv\%20IFDI\%20Report\%20 20201607502893_2100.pdf.

Riazuddin, R. (2011). Challenges of transforming riba-based government debt in Pakistan to Sharī'ah-compliant instruments. Journal of Islamic Business and Management, 1(1), 27-48.

Werner, R.A. (2014). Can banks individually create money out of nothing? - The theories and the empirical evidence. International Review of Financial Analysis, 36(December 2014), 1-19.

Zulkhibri, M. (2019). Halal cryptocurrency and financial stability. In Billah, M. M. (Ed.), Halal cryptocurrency management (pp. 35-49). Cham, Switzerland: Palgrave Macmillan. 